\title{
Considerations Regarding the European System for the Protection of Economic, Social and Cultural Rights
}

\author{
CRISTINA SÂMBOAN
}

\begin{abstract}
Phrased in idealistic terms and having benefited from positive and fastidious correlative obligations, economic, social and cultural rights (ESCR) - also termed "claim-rights" - have long been regarded as "poor relatives" of their elder "brothers", i.e. civil and political rights (CPR) or "liberty-rights", which are surrounded by an aura of historic authority and judicial force. These rights have often been pushed by doctrine towards the field of legal rhetoric. However, jurisprudence has proved that, despite such criticism, ESCR may well be subject to judicial control, either by the indivisibility principle of human rights or interpreting correlative obligations. The article aims to show that, by virtue of its complex structure, the European system for the protection of human rights contributes to enhancing the judicial efficiency of ESCR in social space. The understanding of this phenomenon may be used by the national advocate for a more efficient handling of international instruments for the protection of human rights. The method used here will be the comparative jurisprudential analysis.
\end{abstract}

Keywords: economic, social and cultural rights (ESCR), civil and political rights (CPR), European Court of Human Rights (ECHR), European Committee of Social Rights (ECSR), Court of Justice of the European Union (CJEU), justiciability, jurisprudence

\section{ESCR AND DCP - EQUAL AND INDIVISIBLE RIGHTS, YET SUBJECT TO UNEQUAL JUDICIAL PROTECTION AND DIFFERENT LEGAL TREATMENT}

The legal consecration of economic, social and cultural rights (ESCR) is grounded on the ascertainment that "the ideal of free human beings enjoying freedom from fear and want can only be achieved if conditions are created whereby everyone may enjoy his economic, social and cultural rights, as well as his civil and political rights", in the Preamble of the International Covenant on Economic, Social and Cultural Rights (hereinafter referred to as ICESCR).

The above text, dated 19 December 1966, completed the international construction for the protection of human rights initiated by the proclamation of the Universal Declaration of Human Rights by the General Assembly of the United Nations on 10 December 1948 and carried forward by the enacting by consensus, on 16 December 1966, of the International Covenant on Civil and Political Rights. ${ }^{1}$ In addition, the new Covenant was meant to address the Marxist criticism on human rights, which denounced the "hypocrisy" of speech concerning civil and political rights under the conditions of profound social inequities. ${ }^{2}$

1 Hereinafter abbreviated as ICCPR.

2 In his turn, Anatole France sarcastically referred to the "majestic equality of the law which prohibits both rich men and poor men alike from sleeping under bridges, begging in the street and stealing bread" (Le lys rouge, ch. VII, 1894).

Cristina Sâmboan, Assistant professor, Ph.D. student, Artifex University, Bucharest, Romania. E-mail: cristina@samboan.ro

(Received: 29.01.2014; revision received: 30.03.2014; accepted: 04.15.2014.) 
Despite the appearance of normative symmetry, the two texts set forth different treatments (Etinski 2011: 6). ${ }^{3}$ Correlative obligations incumbent upon signatory States are immediate obligations implying compliance and insurance, in the case of ICCPR, while the terminology of ICESCR is based on the premise of progressive achievement of the rights in question, "within the limits of the available resources". ${ }^{4}$ ICCPR provides for a Committee of Human Rights, while ICESCR ${ }^{5}$ does not provide for a similar body, and a facultative Protocol setting forth a protection mechanism through the opportunity of individual claim submission is in place only with respect to ICCPR, without ESCR enjoying such protection. The attempts to balance the warranty systems only materialized almost half a century later, on 5 May 2013, when a similar facultative Protocol entered into force, finally setting forth, at an international level, the controversial theory of ESCR's capacity to stand in court (Crăciunean 2011). ${ }^{6}$

The European system of human rights gives rise, on a regional scale, to the UN dual and asymmetric mechanism for human rights protection (different legal treatments of CPR and ESCR, the first benefitting from enhanced warranties) in its specific manner, yet characterised by an increased degree of judicial effectiveness and a more coagulated political will of member states to comply with their obligations (Miga-Beșteliu 2003: 202, 224; Gondoin). ${ }^{7}$ Signed in Torino on 18 October 1961, the European Social Charter (ESC) was intended to be a social replica of the European Convention of Human Rights. The latter, that had been entered into more than a decade earlier, ${ }^{8}$ is the first treaty agreed upon within the Council of Europe and being conceived - in the same spirit as the Universal Declaration of Human Rights - as a reply to war experience and an antidote to totalitarianism; protected rights have both a civil and political nature, and although they do not come out in large numbers, the warranty system is, however, really impressive: for the first time people may have recourse to a genuine international jurisdictional instance to complain against their own state for the breach Council of obligations undertaken by the Convention and, furthermore, have a means of obtaining a "fair satisfaction" "for the

${ }^{3}$ For a detailed analysis of the drafting differences between ICCPR and ICESCR, as well as the metabolism of enacting the two Covenants. please see Etinski.

4 Art. 2 of 1 ICESCR.

5 The Committee on Economic, Social and Cultural Rights (CESCR) was set up by the Economic and Social Council of the UN Organization only in 1985 - thus lacking a conventional feature.

6 The Optional Protocol to the International Covenant on Economic, Social and Cultural Rights was adopted on 10 December 2008 by the $63^{\text {rd }}$ session of the General assembly of the UN Organization and was open for signing by all states signing, ratifying or adhering to ICESCR, being scheduled to enter into force within 3 months as of the date when the $10^{\text {th }}$ ratification or accession instrument was deposited. This last condition was fulfilled on 5 May 2013. For a detailed analysis of the content of the Covenant. please see Crăciunean.

7 Space pattern and the subject hereof do not allow a thorough analysis of the effectivness of onusian mechanisms of protection of human rights. It is worth mentioning, however, that the duties of the two committees do not have a jurisdictional nature, their decisions are not binding, and their enforcement is ensured rather by political leverages (please see also Miga-Beșteliu). For a more detailed analysis (please see also Gondoin, accessed: 25.10.2013)

8 The Convention for the Protection of Human Rights and Fundamental Freedoms was signed at Rome, on 4 November 1950, and entered into force on 3 September 1953 (13 years prior to the enacting of ICPCR and ICESCR!)

9 Art. 41 of the Covenant. 
incurred prejudice. Moreover, the court decision is binding and has a direct effect on the internal order of the Member, ${ }^{10}$ while its enforcement is supervised by the Ministries (Shany). ${ }^{11}$

The European Social Charter lacks such warranties and was not even adopted as easily and quickly. It required almost ten years (Voiculescu 2009: 82) to complete and, symmetrically opposite to ECHR, it distinguishes itself especially through the number of the protected rights (economic and social), and less through the control mechanism. A sole mechanism of control was established initially, through the system of reports (Voiculescu 2009: 93-94) ${ }^{12}$ that are to be submitted by each State to the European Committee of Social Rights (hereinafter ECSR), which, based on the reports, issues conclusions on the degree of compliance of national circumstances with the provisions of the Charter. ECSR's interpretation is binding for the respective State - the Charter itself, despite its name, is not a mere declaration of principle, but an international convention mandatory for the states which ratified it - yet there are no specific legal leverages for the control of state compliance with the conclusions of ECSR.

It was only half a century later (November 1995) that an additional Protocol (Voiculescu 2009: 84) ${ }^{13}$ established the procedure of collective claims, ${ }^{14}$ a quasi-judicial system which mitigates the Charter's mechanism of control and entitles NGOs, trade unions or employers' organizations that have consultative status with the Council of Europe, as well as trade unions and employers organizations that are representative at national level, according to the legislation of the respective State, to claim potential non-compliance in respect of Member States with regard to the obligations undertaken by the Charter. However, the claims may not refer to singular cases since, as may be noted, they cannot be submitted by national, non-governmental organizations (other than representative trade unions and employers' organizations). ${ }^{15}$ As regards ECSR decisions, they are binding for the State concerned, but similarly to the reports, no mechanism to impose the enforcement is established.

As may be noted, at both the international and European level - the most elaborated regional system for the protection of human rights - there are significant differences

10 Vermeire v. Belgium, claim no. 12849/87

11 Significant differences compared to recommendations of onusian Committe of Human Rights. For a detailed analysis of CRO effectivness (please see also Shany, accessed: 25.10.2013).

12 This system was nuanced during time. At present, the reports are elaborated depending on the categories 4 topics. For details (please see Voiculescu).

13 During time, the Charter was completed by three additional protocols (1988, 1991, 1995). Therefore, on 3 May 1996, the Revised European Social Charter (hereinafter referred to as RESC) was enacted, replacing the 1961 Charter and including the amendments thereto, as well as new rights. The Charter set forth an unusual ratification system, which allows a certain margin of option for the signatory States by accepting a core of mandatory rights to which a set of other rights is added. This ratification mechanism reflects, in its turn, political sensitivities arising from ESR. Under Law 74/1999, Romania ratified 17 articles, namely 65 numbered paragraphs. For details please see Voiculescu.

${ }^{14}$ A system similar to the one existing within the International Labor Organization.

15 The opportunity to allow the access of national NGOs to the procedure of collective claims is ensured by the Charter, but only to the extent that the States which ratified the additional Protocol dated 1995, execute an explicit statement in this respect. So far, only Finland expresses the political will to allow Finish non-governmental organizations to submit ECSR collective claims. 
between the legal treatments applicable to the two categories of rights: civil and political rights (CPR), on the one hand, and economic, social and cultural rights (ESCR) on the other, and such differences obviously disadvantage ESCR in terms of judicial warranties. It should be noted that this happens against the background of the international consecration of the equal importance and indivisibility of all fundamental rights under the Vienna Declaration of $1993 .{ }^{16}$

\section{ECONOMIC, SOCIAL AND CULTURAL RIGHTS (ESCR) - JUSTICIABLE RIGHTS?}

The disagreeable status of ESCR ("rights of the poor" or "poor rights"?) definitely comes from the way in which they have been expressed in international treaties, in terms that remind one especially of electoral rhetoric than legal terminology. The right to work, the right to food, the right to a minimum income, the right to social security, the right to housing “... Can hunger be eradicated, poverty be fought against, unemployment be eliminated or can general welfare be assured through justice?"17 (Roman 2012) What remedies can give the specific judge of some problems whose solution requires time, staging, a programmatic approach, budget appropriation and so on? Or if they do in fact do it, is this not an interference with the powers of the Parliament - the one which decides on budgetary distribution and the allocation of resources (the democratic argument)? On the other hand, is the judge capable through his specific expertise and by the very nature of his prerogatives - application and interpretation of the law: juris dictio - to provide solutions for issues that require technical, economic, social expertise, bref, a complex approach and "polycentric" intervention (the technical argument)? ${ }^{18}$ (Horowitz 1977: 25-32.) In other words: are ESCR justiciable? Can they indeed be effective in front of the courts? Or are they rather part of the evasive register of legal rhetoric? Who may take such rights seriously, as a matter of fact (Roman 2012: 11) ${ }^{19}$ ?

The key stone of discourse for challenging ESCR is, however, in the distinction based on the type of duties generated by these kinds of rights: positive onerous obligations, contrary to the principle of separation of powers (hence the name, being more or less a pejorative of a "rights-claim") versus the negative comfortable obligations of simple abstention from the state debtor, correlative to the "freedom-rights", the civil and political

${ }^{16}$ Global Conference on Human Rights, Vienna Declaration and Program of Action, 25 June 1993 (UNO doc.A/CONF.157/23), 5 and subseq.

17 Assimilation by law of some social causes and the idea of providing judicial remedies where economic solutions are required have long been sharply fought by the doctrine. For French doctrine difficulties, e.g., to "digest", the insertion in the law of some social or economic programatic objectives and, in general, concerning the justiciability of ESCR, see Roman.

18 The so-called "judicial policy-making". See also Horowitz.

19 The "irony of history": ESCR were meant to be the response to the marxist criticism of the address of the alleged "abstract" character of the revolutionary bourgeois rights, the civil and political ones, which would have meant nothing without the "true", real and concrete rights: social and economic rights. Times have changed, as well as ideologies and, along with them, the concept of human rights: civil and political rights have become the "real" rights, while their poor relatives were evacuated by the doctrine in the box containing "letters to Santa Claus". But times have changed again, ESCR left the letter box and claim, in a more sustained and more successful fashion, the status of "fundamental rights" and an equal place in the panoply of human rights. 
rights. One thing is to require the state to ensure a "right to housing" to all its nationals and another thing is to pretend it to guarantee the citizens' right to free speech or the right to vote, or the right to life. The first aspect requires a program of action, resources, positive actions - easy to enforce, difficult to fulfil, even more difficult to monitor; the second involves simple abstention, non-intervention practices and the performance of obligations is easily accomplished judicially by simply removing the disturbing or injuring actions.

It is not the purpose of this paper to review the opinions expressed over time on the justiciability of ESCR. We confine ourselves to report that this type of discourse, focused on the distinction of "positive obligations vs. negative obligations", dominated with authority for a long time and not with just the specific doctrine, but also with the international meetings, works and debates, concerning the ICESCR (International Covenant on Economic, Social and Cultural Rights) (Roman 2012: 15; Etinski 2011: 4, 5).

While suspicions dominated the legal theory, beneficiaries were taking their rights seriously and the national and international courts were taking their duties seriously, while jurisprudence began to be confronted with the first raids of ESCR from paper into reality. But "on site" confrontation, subjecting ESCR to the tough test of reality, revealed a surprising observation: negative obligations are not the exclusive prerogative of CPR, ${ }^{20}$ just as those positive ones are not a single characteristic of ESCR (Chatton 2007: 53, 54); ${ }^{21}$ achievement progressivity may also cover a $\mathrm{CPR},{ }^{22}$ as immediate execution can be perfectly

${ }^{20}$ Negative obligation of state non-interference may be violated, for example, by a decree issued by the Greek state, which prohibits regular officers from leaving the army earlier than a 25year period into their career, with the consequence of violating the labour right and freedom. Such legislation is assimilated to forced and compulsory labour (Collective complaint 7/2000); or through a legislative amendment which prohibits health care to persons who are illegally in France ("les sanspapiers") and their children with the consequence of breaching the right to health and children's rights provided under Art. 13 and 17 in the Charter (Collective Complaint no. 14/2003); or the systematic practice of the Italian police regarding expulsion or threat of expulsion of homeless people from their places of residence, as well as destruction of their property - which is in violation of the right to housing provided by Art. 31 of the Charter.

${ }^{21}$ Currently, there is almost no provision in the ECHR which should not have been, at a certain time, likely to be enforced through a positive obligation of the State. Positive obligation intervention of the State in the matter of CPR coincides, in fact, in most cases, with the protection obligation corresponding to the intermediate level of stratified obligations. The obligation of protection requires State intervention as regards the injuries to the rights by the third parties and is mainly derived from the provisions of Article 1 of the Convention, which obliges the states to provide for all persons within their jurisdiction, the rights protected by the Convention. The obligation to provide a legislative framework for an adequate and suitable protection to the right in question, violated by the British state by maintaining a law permitting corporal punishment "of reasonable nature" (A. v. United Kingdom), the obligation to make an effective investigation concerning murder, torture or forced disappearances (Guerra and others v. Italy, case no. 14969/89), the obligation to information and advice on harmful emissions of a neighbouring industry, likely to violate the right to integrity, privacy and observance of domicile (Makaratzis v. Greece, case nr. 50385/99) are just a few examples of such obligations. ECtHR casuistry concerning positive obligations is, however, much broader (see also Chatton).

${ }^{22}$ Pilot judgments typically fall very well into this category. In the Oneryildiz v. Turkey, for example (case no. 48939/99), the Court finds that the Turkish state "should have ensured the coordination and cooperation between different administrative authorities (...) so that they do not allow that the risks they have been made aware of [it is about an explosion produced by gases 
compatible with ESCR; in fact, both categories of rights create a varied set of obligations and, briefly, the theory of negative and positive obligations is simply a myth. In its turn, the exegesis of works, reports (Final Observations and Conclusions) and General Observations of control international bodies has also contributed to the mitigating of the cleavage between the two categories of rights, acknowledging the jurisprudential findings (Chatton 2007: note no. 7).

As expected, the doctrine retreated without delay to these findings, ${ }^{23}$ so that, currently, the focus of discourse upon ESCR shifted from the binomial "positive-negative" to the triad of the so-called "stratified obligations": respect, protection and implementation. ${ }^{24}$ Reality is often presented in a various "mixed" way and is not easily subject to the rigors of doctrinal classification. CPR and ESCR are, more exactly, indivisible.

\section{EUROPEAN SYSTEM OF ESCR PROTECTION: EUROPEAN COURT OF HUMAN RIGHTS AND THE EUROPEAN COMMITTEE OF SOCIAL RIGHTS. PARALLEL OR CROSS JURISDICTIONS?}

All these findings obtained international consecration in the conclusions of the Vienna Conference of 1993 and it is no more a subject of great controversy today, but rather an object of further analysis. However, the new theory has not been reflected in the international control and protection mechanisms, political sensitivities being sufficiently acute yet in the area of social claims, so as not to allow a significant progress in procedural terms.

In the European international courts this deficiency is limited to the following question: be it justiciable, as more and more tends to be accepted, can ESCR enjoy real legal protection, equal to that of CPR, since the body designed to provide them (the ECSR) unlike the ECtHR (the competent court as regards CPR) - is not a genuine judicial body, is not competent to settle individual complaints and lacks mechanisms to enforce its decisions which, in case of failure, would lead to a simple recommendation from the Committee of Ministers?25

A first key observation is that, actually, "clipping" is not so trenchant and it often happens that ESCR are, in their turn, engaged under the judicial control of the ECtHR. This apparent extension of competence is achieved in several ways.

On the one hand, under the indivisibility of human rights, perfectly similar situations lend themselves to separate qualifications in terms of violated rights, insomuch as - as a result of such indivisibility - a CPR breach also involves prejudice to an ESCR and they all enjoy the judicial remedies, even if the remedies are aimed at only one of the rights. Thus,

emanated from a dust hole, which led to the death of the plaintiff's family - o.n] worsen to the point of becoming a threat to people's lives". Failing to adopt such measures means that Turkey has violated the right to life. Other examples of cases in which compliance with the rights protected by the ECHR implies fulfillment of some structural obligations: Fadeieva v. Russia (case no. 55723/2000), Broniowski v. Poland (case no. 31443/96), Monnat v. Switzerland (case no. 73604/01).

23 A significant example: Benoit-Rohmer-Grewe 2003.

${ }^{24}$ For a detailed analysis of the application of the "stratified obligations" pattern in relation to all human rights (Chatton 2007: 49-60).

25 The procedure is as follows: after taking the decision, CEDS will submit a report to the Committee of Ministers, which, on this basis, will issue a resolution by a majority of votes. In case of failure, $C M$ adopts a recommendation by a majority of two thirds of the voters (Articles 8 and 9 of the additional Protocol of 1995). 
for example, the term "goods" referred to in Article 1 of Additional Protocol 1 to the Convention also includes claims subject to contributory social benefits; ${ }^{26}$ parental leave allowance is payable under the privacy right provided by Article 8, given the special, biological and psychological relation between parent and child; ${ }^{27}$ dismissal of some tax officials due to the reason of activity passed in KGB service is prohibited not only under Article 14 (prohibition of discrimination), but also under Article 8 (right to privacy); Articles 2, 3 and 8 of the Convention are closely and clearly related to the right to health. Or, in the second aspect (b): the right of access to a public office (protected by the right to work, which is a right not found in the Convention!) is reviewed by the Court under Article 10 (freedom of expression), provided that the refusal is justified by the plaintiff's communist views ${ }^{28}$ and the right to social allowance is reviewed by the Court in terms of Article 6 (right to a fair trial), given that the legislator abolishes legal proceedings covering this type of allowance. ${ }^{29}$ Life confronts us with complex situations which disregard doctrinal distinctions between CPR and ESCR, and the Court intends to take note of this fact (Barac; Petre). ${ }^{30}$

Another 'gateway' of ESCR under the direct control of the ECtHR is the direct one, of the ratione materiae competence, part of the rights protected by the Convention having also social connotations, with the consequence of halving the normative protection. Thus, Art. 4 of the ECHR corresponds to Article 1, second paragraph of the CSEr (prohibition of forced labour); Art. 8 of the ECHR (right to privacy)/Art. 7, 15-17, Art. 31 of the CSEr (right to protection of family, children, disabled persons, the right to housing); Art. 11 of the ECHR/ art. 5, 6 of the CSEr (trade union rights); Art. 2 PA 1 to ECHR/Art. 17 of the CSEr (right to education), and others (Chatton 2007: 69-70). ${ }^{31}$ The principle of non-discrimination may also be a good access way of ESCR for the protection of the Court. ${ }^{32}$

Therefore, despite the initial intentions of the international legislator and any doctrinal prejudices, the areas of competence of the ECtHR and CEDS often interpenetrate and the consequences are just satisfactory for ESCR which therefore enjoys higher protection under the vigorous "umbrella" of the ECtHR.

There are also risks. It is the risk of parallel jurisprudences, of conflicting solutions, of "international litispendence". Since the debtor is unique, and such debtor is the state itself

26 Stec and others v. United Kingdom (cases no. 65731,65900/01).

27 Petrovic v. Austria, case no. 20458/92.

28 Glasenapp vc. Germany, case no. 9228/80.

29 Zielinski and others $v$. France, cases no. 24846/94, 34165/96, 34173/96.

30 The Court itself repeatedly emphasizes that "there is not an impassable barrier ("cloison etanche") to separate the field of economic and social rights by the field of Convention" (Sidabras and Dziautas v. Lithuania, cases no. 55480, 59330/00, paragraph 47). For the lack of an "impassable barrier" ("cloison etanche"), see also Airey v. Ireland (case no. 6289/73) or Stec and others v. United Kingdom (cases no. 65731, 65900/01). For a detailed analysis of economic and social rights in the jurisprudence of the ECHR, see also Petre and Barac.

31 These correspondences should not be regarded as absolute similarities. About "editorial limits" of harmonizing these texts, see also Chatton.

32 See, for example, Zarb Adami v. Malta (case no. 17209/2002), where the plaintiff requested the Court to find that the jury services rendered systematically at the request of the Maltese authorities were forced labour. Although this service is included in the list of exceptions provided for by Art. 4, however, the Court found a violation of the Convention, given the recruitment by the Maltese State, of almost exclusively men, while the number of jury women was practically insignificant. 
(with its authorities), the fact that Court resolutions concern only particular situations, ${ }^{33}$ while collective complaints lead to checking the compliance of a general de facto and de jure situation with the provisions of the Charter, it does not prevent the risk of an institutional blocking or confusing situations for the beneficiaries, in the context of some conflicting decisions. Or, from an even broader perspective, the risk of some non-unitary practices at the European level.

It should also be noted that the differences between international mechanisms for monitoring the enforcement of decisions taken by the two bodies (the ECtHR and ECSR) the resultants, in fact, of a political choice - is not reflected at the national level in an equivalent manner. Because the compulsoriness of interpretations and resolutions provided by the ECtHR and ECSR imposes itself with the same authority in front of a national judge, a state and its authorities, beyond the diversity of enforcement procedures (which is more consistent in the case of the ECHR) (Quesada).

The apparent weakness of ECSR control mechanisms should not be misleading. The international law of human rights is, in fact, a branch of public international law. However, in the complex and delicate equation of relationships of public international law, the effective enforcement of decisions taken by an international court is less dependent on the existence of a sophisticated control system, and rather more dependant on the political will of the State concerned to submit, or that of states interested in exercising political pressures within international bodies upon a guilty state. Nevertheless, in the European regional system, this common political will really exists and maybe it explains to a greater extent the success of the ECtHR than any other argument. And the same political will is the one to ultimately determine the imposing force of ECSR decisions. ${ }^{34}$

As regards interactions between the ECtHR and ECSR over time, the following conclusions can be drawn:

- as it has been foreseen, there were parallel disputes, subject to the same type of case. In these situations, a favourite trend of the ECSR can be noticed toward resolutions which are more favourable for the protection of ESCR; ${ }^{35}$

33 The Court repeatedly emphasized this condition: Botta v. Italy (case no. 21439/93), Jitka Zehnalova and Otto Zehnal v. Czech Republic (case no. 38621/97).

34 An example: as a result of an ECSR report of 1990 (Committee of Independent Experts at that time), Spain changed immediately its poor legislation on compulsory education period. The Committee had noted a gap in the Spanish law, between the minimum age for employment (16 years) and the maximum age for compulsory education (14 years). There remained an uncovered interval of 2 years, where young people could not attend school, nor employ themselves. Spain complied immediately and amended the law in order to establish compulsory education up to the age of 16 . Instead, Belgium needed 11 years to comply with a decision of the ECtHR concerning the abolition of discrimination existing in the Belgian legislation on children born out of wedlock (Marckx v. Belgium, case no. 6833/74). In case of certain collective complaints, partial enforcement occurred even during the course of proceedings (collective complaints no. 33/2006, Mouvement International ATD-Quart Monde v. France and no. 39/2006, FEANTSA v. France) (see interview cited at the previous footnote). Of course, things are not always equally promising, but such examples show that, in spite of the lack of control, the ECSR is, however, taken seriously.

35 Some examples: the Court of Strasbourg has confirmed in Glasenapp and Koziek, the practice of German authorities of dismissing some people from their positions as teachers on the grounds of Nazi (i.e. communist) beliefs which they had, invoking the obligation of loyalty to the State and Constitution - even in cases where the plaintiffs did not express their beliefs during the exercising of their job. However, the ECSR deemed that such practice harms the right to freely 
- some of the initial divergences turn into convergences, over time, given the availability of the ECtHR to inspire itself from the friendlier jurisprudence of the ECSR; ${ }^{36}$

- both bodies use similar legal terminology and base their resolutions on approaching specific international law institutions for human rights. From this point of view, the ECSR may well be assimilated to a jurisdictional body within the rigorous meaning of the term ("juris diction" - to apply and construe the law, to give legal resolutions). ${ }^{37}$ However, the ECSR generally proves to be the promoter of a strongly argued jurisprudence, net favourable for the valorisation of ESCR;

- relations between the two bodies are characterized by a certain "professional reverentiality" evidenced by: mutual references, mutual influencing, willingness to use the practice of the other as inspiration, ${ }^{38}$ concern for harmonization and avoidance of conflicting resolutions. This tag does not go so far as to affect their independence and prevent them, when necessary, from releasing opposite resolutions.

All these elements are encouraging for ESCR's beneficiaries, collective complaints becoming a generous option, always handy and more inviting as they are not subject to the limitation of domestic remedies and, in addition, they are addressed to a qualified and benevolent "ear" (the ECSR). Things obviously are less reassuring for the state, as a debtor of ESCR, which, on the supposition of some contradictory resolutions, may certainly find itself in a disagreeable situation.

Finally, some necessary considerations must be made on the place of the Luxembourg Court in the European regional legal "galaxy", as well as the role and possible added value brought by the Charter of Fundamental Rights in the legal subject area of ESCR.

exercise a profession. Subsequently, the Court, inspired by the ECSR, revised its position in the case Vogt v. Germany through a highly controversial decision (but with only one dissenting opinion). Another parallel judgement had to deal with the assimilation of forced labour of the civil service replacing the military one. The jurisprudential line of the Court was to reject such an approach, so that such types of demands began to be based on ... conscientious objection! The ECSR, however, stated that the civil service can be assimilated into forced labour, especially when its duration is disproportionate (RC no. 8/2000, QCEA v. Greece).

36 In relation to trade union freedoms, the Court admitted, in an initial phase, the "closed-shop" clause (Sibson v. the United Kingdom case no. 14327/88, Young, James and Webster v. UK cases no. $7601 / 76,7806 / 77$ ) which, instead, in the case $S N$ v. Sweden (RC 12/2002), the ECSR considered as unacceptable. Subsequently, the Court incorporated this approach in its jurisprudence, in the case Sørensen et Rasmussen v. Denmark (cases no. 52562, 52620/99) and in Demir and Baykara v. Turkey (cases no. 34503/97) where the Court expressly refers to ECSR jurisprudence.

37 Notions like "living instrument", "effective rights", "evolutionary interpretation", "margin of appreciation", etc. are recurrent in the terminology used by the ECSR. Also the interpretations of the Committee have a legal nature. Moreover, all members of the ECSR have achieved higher legal education (the list containing their names is available online at: http://www.coe.int/t/dghl/monitoring/ socialcharter/ ecsr/members_EN. asp, last accessed on 25.10.2013).

38 References to ECtHR jurisprudence are nearly ubiquitous in the resolutions of the ECSR. For ex.: QCEA v. Greece (paragraph 22), AIAE v. France (paragraph 52), ERRC v. Greece (paragraph 20) and many others ... References of the ECHR to the jurisprudence of the ECSR / CSEr (examples): Zielinski et al. v. France, Stec et al. v. United Kingdom, Vitiello v. Italy, Campagnano v. Italy, etc. 


\section{THE COURT OF JUSTICE OF THE EUROPEAN UNION (CJEU) AND ESCRS. INTERFERENCES WITH THE JURISPRUDENCE OF THE ECTHR AND EUROPEAN COMMITTEE OF SOCIAL RIGHTS (ECSR). THE CHARTER OF FUNDAMENTAL RIGHTS OF THE EU - AN ADDED VALUE?}

\subsection{Dialogue between the two Courts, the ECtHR and CJEU}

The ECtHR and CJEU have been developing over time a "strategic harmony" (Paris 2012: 168) type of relationship, which eloquently references a mutual politeness and thoughtful concern meant to maintain a continuous coordination between the two systems.

This relationship is based, however, on the premise of the ECtHR's discrete "paternal" authority. On the one hand, when first attempting to develop a human rights doctrine within the Union - based on a considerable regulatory deficiency on this subject at the community level, until the 1992 TUE - the Court of Justice acknowledged the ECHR's 39 "special meaning" as a source meant to inspire with its jurisprudence integrating approach to these rights. ${ }^{40}$ This consecration marked the beginning of a judicial activism which is supported by various references to the ECtHR's ${ }^{41}$ jurisprudence and regulated in the European Union's Charter of Fundamental Rights (the "Charter"), first proclaimed in December 2000, as adapted and proclaimed for a second time in December 2007, when it entered into force when the Lisbon Treaty was signed.

The Charter represents the expression of respect towards the Strasbourg Court, as its formulation was based on the Convention and the ECtHR jurisprudence. ${ }^{42} \mathrm{~A}$ great number of rights have been reproduced, ${ }^{43}$ and others codify the European jurisprudence, ${ }^{44}$ Art. 52 p. 3 assigns ECHR interpretation as the Chart's interpretation benchmark, and Art. 53 converts it into the minimal protection standard (the favor libertatis clause).

As to the Strasbourg Court, its reference to the CJEU's jurisprudence is complex and denotes a subtle, yet well-dosed balance between, the monitoring necessity, on the one hand, and respect for the EU's autonomy and specific legal order ${ }^{45}$ on the other hand. Approaching the delicate issue of monitoring the Union's legislation stems from this premise: there is nothing preventing the Convention signatory states from transferring their prerogatives to an international organization; however, this does not include the transfer of responsibility towards that organization, as the state will still be held responsible for any

39 Rutili v. Minister for the Interior (case 36/75).

40 Other sources being: "international instruments for the human rights protection at which the Member States cooperated or which they adopted" (Nold v. Commission, case 4/73), "Member States constitutional traditions" (Hauer v. Land Rheinland-Pfalz, case 44/79).

41 "The Court of Justice often applies the Convention, especially the ECHR's jurisprudence CEDO" (The CJUE's think piece (document de reflecție) regarding certain aspects of the European Union's accession to the European Convention for the Protection of Human Rights and Fundamental Freedoms, May 5, 2010, Luxembourg (pgf. 1.3.). See also Elinki Radiophonia Tileorassi (C-260/89), or Omega Spielhallen (C-36/02).

42 In the Presidium's Explanations, the ECHR's importance is repeatedly pointed out (The explanations on the Chart of fundamental rights, published in the OJ /14.12.2007 (C-303) and attached to the Charter).

43 Almost half of the Charter's provisions have an equivalent in the ECHR (Art. 2, Art. 4-7, Art. 9, Art. 10 p. 1, Art. 11 p. 1, Art. 12 p. 1, Art. 14, Art. 17, Art. 19 p. 1, Art. 21, Art. 45, Art. 47-50).

44 E.g. Ahmed v. Austria (case no. 25964/94) or Soering c. Regatului Unit (case no. 14038).

45 For a detailed analysis of the ECtHR - CJEU relationship (Paris 2012: 149-178). 
infringement of the liability originating from this Convention. ${ }^{46}$ And this implies an indirect control of the EU's legislation via these national implementation measures. ${ }^{47}$

Faced with disputes regarding the national implementation measures of the EU's legislation, in an attempt to conciliate the Convention legislation with the EU's specific legal order, the Court has been poised between the necessity of firm intervention ${ }^{48}$ and cautious "self-restraint". 49

The Strasbourg Court's position towards the CJEU is not only about this discrete authority relationship, but also involves receptivity towards the latter's jurisprudence. On the one hand, we have a series of references to the CJEU's solutions ${ }^{50}$ (which denotes among others a concern to maintain the coherence between the two systems), and on the other hand, an increase in references to the Charter - which is indeed remarkable as the first reference happened even before the Charter came into force, and even before the CJEU refers to it! ${ }^{51}$

It goes without saying that the success of this productive jurisprudential dialogue was reached when negotiations began regarding EU accession to the ECHR. ${ }^{52}$

That is all well and good, but it is not relevant to economic, social and cultural rights. It is true, as it has been proven, they can ricochet under the ECtHR's jurisdiction - thus influencing the CJEU's jurisprudence, especially after the EU's accession to the CJEU - but these cases cannot be widespread and they will still remain under the Strasbourg Court's specific responsibilities deviation category.

\subsection{ESCRs in the CJEU's Jurisprudence}

As to ESCRs protection within the EU - at least until the Charter's adoption as primary legislation - they hypothetically enjoyed the same protection as CPRs: they did not exist as regulation, but were assumed by the Court as jurisprudence with reference to the common constitutional traditions and the international treaties.

${ }^{46}$ Matthew c. Regatului Unit, case no. 24833/94, 32.

47 A situation which will of course change once the EU accesses to the ECHR. From that moment on, the EU will be directly controlled by the Court (see also Paris 2010: 179). This position was highlighted via an important decision (the Bosphorus decision) establishing it as a necessary condition when applying EU legislation at a national level (when the state does not benefit from the appreciation margin) to ensure the fundamental rights protection which is at least the same as the protection ensured by this Convention.

48 M.S.S. v. Belgium and Greece, case no. 30696/09, directly concerning the Dublin asylum system. Very well describing the relationship between the two Courts, therein analyzed, is the immediate integration by the CJEU of this solution into its own jurisprudence (N.S./Secretary of State for the Home Department and M.E. and others./Refugee Applications Commissioner and Minister for Justice, Equality and Law Reform (C-411, 493/10).

49 Emesa Sugar c. Olandei, case. no. 62023/00 - the Court of Srasbourg refused to intervene in the CJEU's procedures, on the basis of Art. 6 of the Convention (infringement of the right to a fair trial).

50 E.g., Stec v. UK (cases no. 65731, 65900/01) or DH v. Czech Republic (case no. 573250/00).

51 E.g., Bosphorus, Christine Goodwine, Sørensen et Rasmussen, Demir și Baykara...

52 See also The Draft legal instruments on the accession of the European Union to the European Convention on Human Rights, July 19, 2011, CDDH-UE (2011)16. For information regarding the accession consequences (Kokott-Sobotta 2012: 93-111). 
In exercising its specific EU legislation interpretation and implementation powers in the context of the relationships established by the Internal Market, the CJEU developed social jurisprudence which is rich and interesting (but nonetheless contentious). Even so, unlike the situations in which ESCRs were involved and where the Court does not scruple to reference the ECtHR's jurisprudence, such references to international treaties - i.e. the European Social Charter - or national constitutions, appear only occasionally amongst the Court's decisions dealing with ESCRs. The CJEU seems less willing to efficiently draw on specific ESCRs protection treaties, or the ECSR's specialized jurisprudence, even if it proclaims it will do so.

The CJEU acting this way only lead to the development of its own social jurisprudence, which is sheltered from any dedicated international benchmark. This is even more serious as, given it is subject to EU legislation which should interpret and apply it, the vast majority of the Luxembourg Court's decisions are of a social nature and entail ESCRs, not CPRs. Let's not forget that until Lisbon, the Court ruled only on economic and Internal Marketrelated issues, corresponding to the scope of the first "pillar" of EU, while issues relating to the "area of freedom, safety and justice", namely the most competent with respect to bringing into discussion the CPRs observance, came under the CJEU's control only when the Lisbon Treaty came into force. ${ }^{53} \mathrm{We}$ are obviously not stating that CPRs are vulnerable only in terms of criminal matters. Clearly there are many other ways CPRs could go under the Court's supervision - work and social security, via human rights indivisibility, relationship with EU institutions ${ }^{54}$ non-discrimination principle, EU citizenship, etc. (as a matter of fact, CPRs are by their very nature a permanent probability in the meaning of whichever situation) - which is what actually happened. This only points out the fact that social issues have a preferred spot within the jurisprudence of the Luxembourg Court, these issues are automatically highlighted around ESCRs and hence, in this context, it was desired and expected that the Court consistently refer not only to the ECtHR's jurisprudence, but to the ECSR's practice and jurisprudence too. Which surprisingly happened only by accident.

This unbalanced approach was hence reflected within the EU when the EU Charter of Fundamental Rights was adopted. The Charter preamble states that the Presidium's Explanations must be used to interpret it. And, although the European Social Charter is mentioned in the Preamble as well as the European Convention on Human Rights, the explanations only refer to the latter, i.e. ECtHR jurisprudence, and to the European Social Charter, and not to the ECSR's jurisprudence! Referencing only to the European Social Charter is not much as the rights it protects are included in the EU Charter, and, moreover, the EU Charter contains a lot more rights that are protected.

This deficiency is unfortunate as the Luxembourg Court's social jurisprudence has been heavily criticised over time. This jurisprudence is characterized by a very strenuous activism of the Court to accelerate accession and complete the Unique Market. The Court

53 Art. 67 TFUE placed the "third pillar" in the Union's competence area. Even so, although only occasionally, the Court of Luxembourg did not miss the chance to give a decision, even controversial, on the alleged indirect effects of laws adopted within the third ex pillar, although the former JHA was excluded from its sphere of competence (C-105/03 Criminal Proceedings against Maria Pupino [2005] ECR I-5285).

54 Although, as we know, individuals' access to proceedings against European institutions (former Art. 230 TUE) was heavily conditioned (see also Plaumann v. Commission, 25/62). Art. 230 was replaced by the current Art. 263 TFUE, somewhat improving the state of things as it keeps the direct interest requirement, but eliminates that of the individual interest. 
seems so absorbed in this accession effort that when performing its "uniform interpretation" of EU legislation, it gave treaties unexpected meanings that would surprise even the founding fathers (Sâmboan 2010). ${ }^{55}$

Besides, in its interpretations, the Court often removes areas in the exclusive competence of the states and subjects them to the Internal Market integrationist harshness. To justify its position, the Court resorts to the following logic: is it true that in the respective domain (i.e. national social security system or health insurance), the Member States retain autonomy, but this autonomy does not eliminate the need to apply the EU law, namely the current Art. 56 and 57 TFUE. ${ }^{56}$

To which degree can this approach - being obviously detrimental to Member States sovereignty - favour ESCRs, is debatable. For example, the acknowledgement of the applicant's possibility to receive better health care in another Member State's hospital, because of the national healthcare plan offered by their own state, it initially seems to be at first a better solution for patients. But when applied on a larger scale, this solution can unbalance national healthcare systems, as it will bring considerable financial pressure upon them, and this will first put at a disadvantage the low-income individuals who cannot afford to pay the high travel costs between states (O'Gorman 2011: 1833-1861). The same logic can be applied to several other similar decisions of the Court, ${ }^{57}$ and the conclusion is not always beneficial to ESCRs.

The only thing the Luxembourg Court does is fulfil the tasks it received: uniform application of treaties aiming to create an internal market where goods, people, services and assets move freely. This is not a legal objective, but rather a political one. And this ambivalence of EU legislation weighs down on the Court's activity, preventing it from acting as a neutral legal body, a characteristic of each legal authentic body.

The adoption of the Fundamental Rights Charter seems beneficial in this context as, for the first time in the EU's history, a clear ESCRs catalogue has the same legal power as the treaties. But art. 51 (1) of the Charter mentions that it addresses only those situations

55 For instance, it is hard to believe that by the term "workers" the treaties' authors and signatories considered those looking for a job (Royer - 48/75; $R$ vs. Immigration Appeal Tribunal, ex parte Antonissen - 292/89), or that by workers' "family members" the authors considered their partners (Netherlands vs. Reeds - 59/75), or that regarding the possibility to stay on the territory of the Member State after the end of the employment, the authors also considered those who lost their jobs, or that the rights bound to European citizenship (stipulated in a rigorous and restraining way by TUE) could be extended into the Member States' social insurance area (Grzelczyk-184/99), etc. The Court brought so many important changes in this area, that they have been integrated into the EU law (Directive 2004/38/EC), which brings up a new dimension of the EU democratic deficit.

${ }^{56}$ Kohllv.Union des Caisses de Maladie, 1998 E.C.R. I-1937; Geraets-Smits \&Peerboms, 2001E.C.RI-5473; V.G. Mulle-FauréandE.E.M. van Rietv Onderlinge Waarborgmaat schappij ZAOZorgverzekeringen, 2003 E.C.R.I--4509; Watts v. Bedford Primary Care Trust, 2006 E.C.R.I-4325.

57 The weaknesses of this jurisprudential approach have been revealed on the occasion of the controversial "Quartet Laval": a set of solutions that Court gave consecutively from 2005 to 2006, and which perfectly highlighted the conflict between social rights (union-related rights in this case) and the internal market integration requirements. The analysis of these decisions' impact on the Member States' social policies was heavily discussed in the literature. (C-438/05 International Transport Workers' Federation (ITF) and Finnish Seamen's Union (FSU) v. Viking Line; C-341/05 Laval un Partneri v. SvenskaByggnadsarbetareförbundet; C-346/06 Dirk Rüffert v. Land Niedersachsen). 
where the EU's law is to be applied. This note (for which the Charter has been heavily criticised) (O'Gorman 2011: 1857) brings about a brutal flat effect, namely it maintains the conflicting nature of "fundamental rights - freedoms of the market" binomial.

This is why referencing ECSR's solid expertise and generous, neutral and wellbalanced jurisprudence, would be welcomed. And this is also probably why this jurisprudence is so tenaciously avoided.

\section{CONCLUSIONS}

The existence of three European judicial bodies dealing with ESCRs benefits them. But this praetorian triangle is imperfect and we can symbolically shape it at an angle where the top is the ECtHR to which the CJEU and ECSR are tied, but without any similar relation between the last two.

The fact that the ECtHR is the one which enjoys the link statute somewhat diminishes the system's weaknesses, as it is at the same time the strong one: its decisions are not as fragilely enforceable as the ECSR's solutions, and its jurisprudence is protected from political conditioning unavoidably affecting the CJEU. Hence the authority it has compared to the other two and the legal role model it became over time can vigorously influence their activity.

The major disadvantage of the system is that the ECtHR ensures ESCRs protection only indirectly. The true authority specializing on ESCRs is the ECSR. Ergo re-establishing this third connection, between the CJEU and ECSR, could greatly contribute to the clever stabilization of the tumultuous relationship between the Internal Market and ESCRs. Thanks to its thorough expertise and impartiality, the ECSR could offer solutions to the CJEU to resolve the complex issues which it has to deal with. But in order to accomplish this, the EU judge must listen to the ECSR's suggestions ${ }^{58}$. It is needless to say that the EU's accession to the European Social Charter is the most desirable alternative.

Beyond these weaknesses, the superiority of the ESCRs European protection system is unquestionable and it is this richness in instruments that ensures its drive and vigour.

\section{REFERENCES}

Barac, L.: Convenția Europeană a Drepturilor Omului, drepturile sociale și economice, (European Convention on Human Rights, Social and Economic Rights). "Supliment legal" ("Legal Supplement"), available at: http://www.just.ro/LinkClick.aspx?fileticket=m7cljInR 29A\%3D \&tabid $=1571$

Chatton T. G. (2007): L'harmonisation des pratiques jurisprudentielles de CEDH et du CEDS: une evolution discrete. Harmonisation International du Droit, Geneva

Crăciunean, L.-M. (2011): Protocolul opțional la Pactul Internațional privnd drepturile economice, sociale și culturale: o nouă eră pentru drepturile culturale? (Optional Protocol to the International Covenant on Economic, Social and Cultural Rights: A New Era for Cultural Rights?) Noua Revistă de Drepturile Omului (1)

58 Interferences between the ECtHR, CEDS and CJUE's jurisprudence are almost unavoidable. It is easy to imagine collisions in common areas such as social taxes and benefits, health care, the right to work - areas available to CURIA via non-discrimination on the basis of nationality, ECHR, via Art. 1 from the Additional Protocol 1/ECHR, or CEDS on the basis of several provisions from CSEr (Art. 2, 12, and 13). 
Etinski, R. (2011): Controverse privind controlul judiciar al respectării drepturilor economice, sociale și culturale (Controversies on Judicial Review of Compliance with Economic, Social and Cultural Rights). Noua Revistă de Drepturile Omului

Gondoin, E.: L'efficacité du Pacte International relatif aux Droits Civils et Politiques en droit interne face aux mécanismes de droit international et au régionalisme de la protection des Droits de l'Homme. available at: http://m2bde.u-paris10.fr/content $/ 1 \% \mathrm{E} 2 \% 80 \% 99$ efficacit $\%$ C3\%A9-dupacte-international-relatif-aux-droits-civils-et-politiques-en-droit-interne

Kokott, J.-Sobotta, C. (2012): The Charter of the Fundamental Rights of the EU after Lisbon. Revista Română de Drept European (5)

Miga-Beșteliu, R. (2003): Drept Internațional. Introducere în dreptul internațional public (International Law. Introduction to Public International Law). ALL Beck.

O'Gorman, R. (2011): The ECHR, the EU and the Weakness of Social Rights Protection at the European Level. German Law Journal, 12(10), available at: www.germanlaw journal.com/pdfs/ Vol12-No10/PDF_Vol_12_No_10_181861_Articles_O\%5C'Gorman.pdf

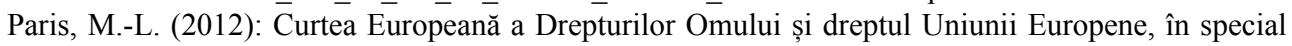
Carta Drepturilor Fundamentale: o gestiune subtilă între ajustări sistemice și îmbogăţiri reciproce (European Court of Human Rights and European Union law, in Particular the Charter of Fundamental Rights: A Subtle Management between Systemic Adjustments and Mutual Enrichment). Revista Română de Drept European (2)

Petre, I.: Drepturi bănești în jurisprudența CEDO (Financial rights in the ECHR Jurisprudence). "Supliment legal" ("Legal Supplement"), available at: www.just.ro/LinkClick. aspx?fileticket=m 7cljInR29A\%3D\&tabid=1571

Quesada, L. J.: La charte sociale a 50 ans. Réflexions de l'intérieur autour d'un anniversaire. available at: http://www.raison-publique.fr/article501.html

Rohmer, F.-Grewe, C. (2003): Les droits sociaux ou la demolition de quelques poncifs. Presses Universitaires de Strasbourg, P.U.S.

Roman, D. et al. (2012): "Droits des pauvres, pauvres droits?" Recherches sur la justiciabilite des droits sociaux. available at: http://revdh.files.wordpress.com/2012/06/droits-des-pauvres-pauvresdroits.pdf

Sâmboan, C.: Curtea Europeană de Justiție, legislatorul din umbră al Uniunii Europene (The European Court of Justice, the Legislator of the Shadows of the European Union). Revista Univ. ARTIFEX (Revue of ARTIFEX University), dec. 2010.

Shany, Y.: The Effectiveness of the Human Rights Committee and the Treaty Body Reform, available at: http://papers.ssrn.com/sol3/papers.cfm?abstract_id=2223298

Țiclea, A. (2013): Din soluțiile Curții de Justiție a Uniunii Europene și ale Curții europene a drepturilor omului în materia raporturilor de muncă (From the Solutions of the Court of Justice of the European Union and the European Court of Human Rights in the Field of Labor Relations). Revista Română de Dreptul Muncii 6: 27-32.

Voiculescu, N. (2009): Drept comunitar al muncii (Community Labor Law), Wolters Kluwer, Bucharest, as well as http://www.coe.int/t/dghl/monitoring/socialcharter/Report Calendar/ CalendarNRS_fr.asp 